\title{
Mulher e Saúde
}

A atenção à saúde da mulher, na história das políticas de saúde no Brasil e no mundo, tem sido reduzida, em grande parte, aos parâmetros da atenção materno-infantil e, mesmo assim, freqüentemente, relegada a segundo plano.

Com o desenvolvimento de estudos sobre a mortalidade perinatal e infantil em geral (incluindo o efeito do espaçamento das gravidezes) é cada vez mais evidente que esta abordagem tradicional não é adequada nem à proteção da saúde da infância, nem para resolver a questão da mortalidade matema.

No Brasil, a política pública evidenciou um salto de qualidade na década de 80 , com a formulação de propostas de atenção integral à saúde da mulher (PAISM-MS; Resolução 123 do Inamps) que incluíram, pela primeira vez, serviços públicos de contracepção, e que visavam à incorporação da própria mulher como sujeito ativo no cuidado da sua saúde, considerando todas as etapas de vida. Ainda falta muito para uma efetiva implementação destas propostas.

A ampliação do conceito de saúde, refletida parcialmente nestas mudanças, faz parte das reivindicaçōes do movimento de mulheres, que vem participando da promoção da saúde da mulher em todos os níveis. Nas Conferências Nacionais de Saúde e Direitos da Mulher, em 1986 e 1989, os temas de saúde mental, sexualidade, aborto, adolescência, velhice, trabalho e saúde e saúde e cidadania foram destacados como áreas essenciais que exigem avanços urgentes.

Ao nível conceitual, a ampliação do conceito de saúde é fruto de análises da condição feminina que abrangem as esferas de produção e de reprodução e que abordam as complexas relaçōes entre ambos, tanto a nível das práticas sociais como a nível ideológico. Este campo de estudo, de natureza multidisciplinar, inclui desde análises históricas de estereótipos culturais até avaliações de tecnologias reprodutivas de ponta.

É neste contexto que a área temática Mulher e Saúde vem a ser inserida no Programa de Mestrado e de Doutorado em Saúde Pública da Ensp, e que apresentamos este primeiro número especial dos Cadernos de Saúde Pública sobre o assunto.

Os trabalhos aqui incluídos abordam, na sua maior parte, temas que extrapolam as questões da saúde materna, refletindo tanto o esforço de desenvolvimento conceitual como uma preocupação com a implementação de serviços que lidam com a mulher como ser integral.

Assim, temos uma análise histórica do estabelecimento da "arte obstétrica" no Brasil, que demonstra 
a perda de controle deste conhecimento pelas mulheres, e o início da sua incorporaçâo à prática médica. Outro artigo traça um retrato atualíssimo da situação do parto no pars, onde a intervenção tecnológica, através da operação cesária sobreutilizada, vem a representar um risco à saúde, e a revalorização do parto natural e vaginal é posta como necessária.

$\mathrm{O}$ artigo sobre a mortalidade feminina elabora este perfil a nível nacional, contextualizado numa discussấo das mudanças no papel da mulher que tanto acompanham as tendências internacionais como divergem delas na qualidade dos fatos gerados numa situação de crise e precárias condições de vida.

Duas análises conceituais - que enfocam, respectivamente, a relação trabalho, mulher e saúde, e a dialética do biológico e do social - têm em comum a preocupação em avançar numa caracterização da condição feminina que leva em conta a conformação atual da articulação entre as esferas de produção e de reprodução.

Os trabalhos sobre violência, aborto induzido, e AIDS e a Mulher trazem novos dados locais sobre temas que, até recentemente, têm sido relativamente pouco estudados - o que, no caso dos dois primeiros assuntos, ilustra o processo histórico de ocultamento de aspectos da vida da mulher que são ideologicamente inconvenientes às sociedades ainda patriarcais.

A transformação da relaçảo entre profissionais de saúde e mulheres, que permite às mulheres surgirem como sujeitos ativos de uma história de vida, é tema de dois artigos que abordam esta questão, em um caso através de uma elaboração dos significados presentes nesta relação, em outro caso na forma de um relato de experiếncia na consulta coletiva em ginecologia que mostra a viabilidade e os beneffcios de trabalhar, concretamente, para esta transformação.

Temos certeza de que este conjunto de trabalhos será bem recebido pelos profissionais engajados na tarefa de construir um conhecimento sobre a mulher e a saúde que possa contribuir para a formulação polf́tica e sua operacionalização.

Apontamos, para finalizar, que (com duas honrosas exceçōes) todos os autores aqui incluídos são mulheres. Indagamos, aos leitores, se este fato deve ser interpretado como indicador de progresso, no sentido de novo espaço profissional conquistado pelas mulheres, ou como evidência da recuperação do espaço antigamente dominado pelas mulheres, ou simplesmente como sinal da continuada estruturação dos espaços sociais em função do sexo?

Karen Mary Giffin

Professora Visitante do Depto. de Ciencias Sociais da Ensp/Fiacruz 